2. To: (Receiving Orgenization)

5. Proj./Prog./Oept./Div.:

84100

8. Originator Remerks: transport a total of less than $10 \mathrm{~A}_{2} \mathrm{~s}$ from the 325 Building to the burial grounds. The attached SEP is being submitted for review, approval, and release.
11. Receiver Remerks:
114. Deefion saseline Document?
[] rea
[X] No

Packaging Engineering

Two boxes designed for the Plywood Box SEP will be used to
3. Fram: (Originating orgenization)

Packaging Engineering

. Desion Authority/ Design Asent/Cog.

Engr.:

B. D. Flanagan
4. Related EDT Mo.:

NA

7. Purchase Order No.:

NA

9. Equip./Component No.:

NA

10. Systemplde./Facility:

NA

12. Mojor Asen. Oug. No.:

NA

13. Perdit/Parmit Application No.: NA

14. Required Response Date: September 25, 1996

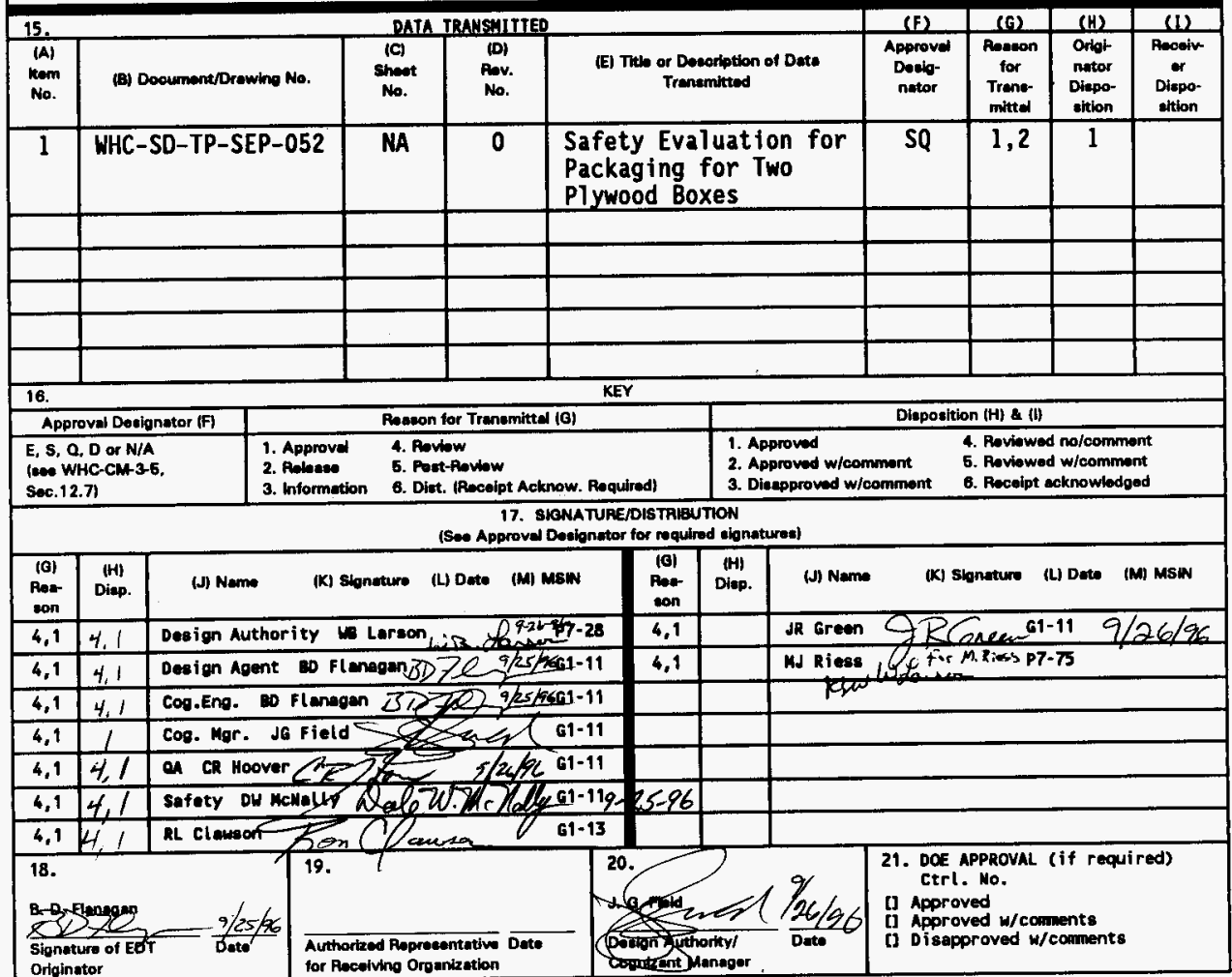

BD-7400-172-2 (05/96) GEF097 


\section{Safety Evaluation for Packaging for Two Plywood Boxes}

B. D. Flanagan

West inghouse Hanford Company, Richland, WA 99352

U.S. Department of Energy Contract DE-AC06-87RL10930

EDT/ECN: 618182 UC: 513

Org Code: 84100 Charge Code: BE0739

B\&R Code: YNO100000 Total Pages: 16

Key Words: transport, $A_{2} s, 325$ Building, burial grounds

Abstract: This safety evaluation for packaging authorizes onsite transport of a total of less than $10 \mathrm{~A}_{2} \mathrm{~s}$ in two plywood boxes from the 325 Building in the 300 Area to the burial grounds in the 200 West Area.

TRADEMARK DIscLAImER. Roference herein to eny spociflc comencial product, process, or service by trede nem, tredemerk, mufecturer, or otherwise, does not necesespily conetitute or inply its endorseenent, recomendation, or fovoring by the United stetes covernment or eny agency thereof or its contrectors or eubcentrector:

Printed in the United stotes of amrice. To obtoin copies of this docuent, contect: UHC/BCS Docuent Control Services, P.0. Box 1970, Milstop H6-08, Richlend wh 99352, Phone (509) 372-2420; Fax (509) 376-4989.
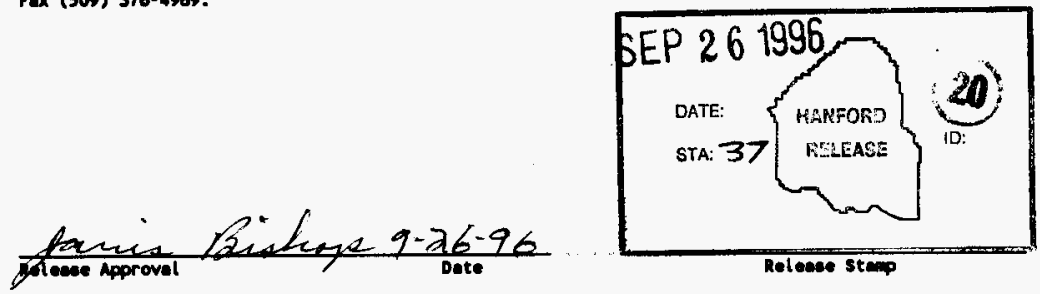
WHC-SD-TP-SEP-052 Rev. 0

CONTENTS

PART A: DESCRIPTION AND OPERATIONS

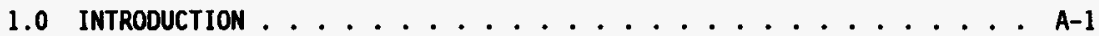

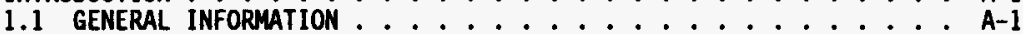

1.2 SYSTEM DESCRIPTION . . . . . . . . . . . . . . . . . A-1

2.0 PACKAGING SYSTEM ....................... A-1

3.0 PACKAGE CONTENTS ................... A-2

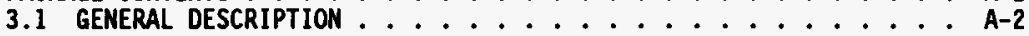

4.0 TRANSPORT SYSTEM . . . . . . . . . . . . . A-2

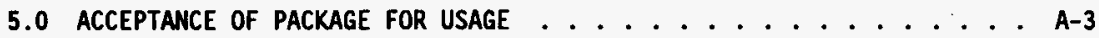

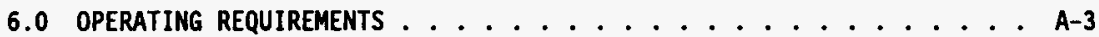

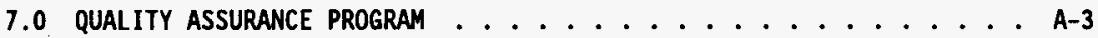

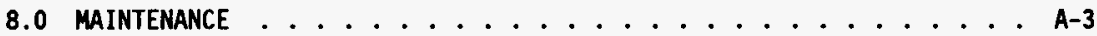

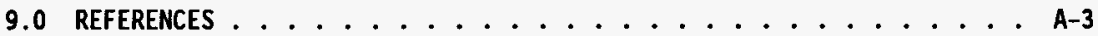

\section{PART B: PACKaGe EVALUATION}

1.0 INTRODUCTION . . . . . . . . . . . . . B-1

1.1 SAFETY EVALUATION METHODOLOGY . . . . . . . . . . B-1

1.2 EVALUATION SUMMARY AND CONCLUSIONS ................ B-1

2.0 CONTENTS EVALUATION . . . . . . . . . . . . . B-1

2.1 CHARACTERIZATION ...................... B-1

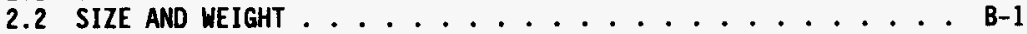

3.0 RADIOLOGICAL RISK EVALUATION ................ B-2

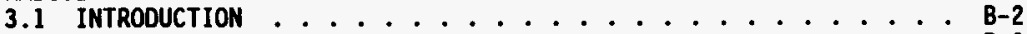

3.2 RISK ACCEPTANCE CRITERIA ............... . . B-2

3.3 ACCIDENT FREQUENCY ASSESSMENT . . . . . . . . . . . . B-3

3.4 DOSE CONSEQUENCE ANALYSIS .............. B-3

3.5 RISK EVALUATION AND CONCLUSION ............. B-3

4.0 CONTAinMEnt EVAluation . . . . . . . . . . . . B-4

4.1 CONTAINMENT SOURCE SPECIFICATION $\ldots \ldots \ldots \ldots$

4.2 NORMAL TRANSFER CONDITIONS ................ B-.

4.2.1 Containment Evaluation ................. B-5

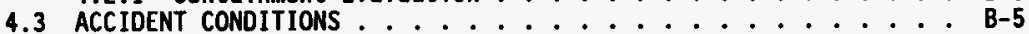


5.0 SHIElding EVALUATION ..................... B-5

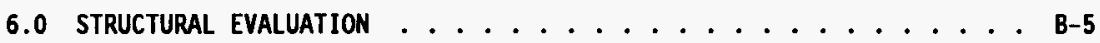

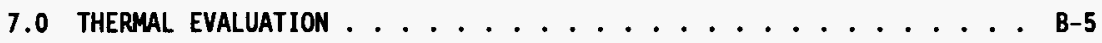

8.0 PRESSURE AND GAS GENERATION ................. B-5

9.0 PACKAGE TIEDOWN SYSTEM ................... B-6

10.0 REFERENCES ..................... B-6

11.0 APPENDIX: SOLID WASTE STORAGE/DISPOSAL RECORDS . . . . . . . B-7

\section{LIST OF TABLES}

A-1 Nuclide Content ................... A-2

B-1 Nuclide Content ................. B-2

B-2 Total Effective Dose Equivalent Spreadsheet . . . . . . . . B-4 
WHC-SD-TP-SEP-052 Rev. 0

SAFETY EYALUATION FOR PACKAGING FOR TWO PLYWOOD BOXES

PART A: DESCRIPTION AND OPERATIONS

\subsection{INTRODUCTION}

\subsection{GEMERAL IMFORMATION}

This safety evaluation for packaging evaluates and documents the ability of the plywood boxes listed below to meet the packaging requirements of WHC-CM-2-14, Hazardous Material Packaging and Shipping, for the onsite transfer of Type $B$ radioactive material. Onsite transfer is the transport of hazardous materials on controlled routes confined to established limited areas and to portions of federally owned roadways to which public access is prohibited during transfer.

The plywood boxes being used for this transport are PIN number PNLD-95-322 and PNLD-95-385. The contents being transported are wood, plastic, piping, rubber, and gloves. The source term was determined by nondestructive analysis and obtained from the solid waste storage/disposal record.

Before the nondestructive analysis, the intention was to transport the boxes under WHC-SD-TP-SEP-020, Safety Evaluation for Packaging (Onsite) Plywood Box (WHC 1994), but Type B shipments are not included.

\subsection{SYSTEM DESCRIPTION}

The package system consists of a plywood box $1.22 \mathrm{~m}(4 \mathrm{ft})$ wide by $2.58 \mathrm{~m}$ $(4 \mathrm{ft}, 5.5 \mathrm{in}$.) high by $2.44 \mathrm{~m}(8 \mathrm{ft})$ long that is lined with one sheet of minimum $0.15-\mathrm{mm}(6-\mathrm{mil})$ piastic and loaded with solid waste contaminated with Type $B$ radioactive materials. A complete system description and figures are listed in WHC-SD-TP-SEP-020 (WHC 1994).

\subsection{PACKAgING SYSTEM}

A complete description of the packaging system is listed in WHC-SD-TP-SEP-020 (WHC 1994). 
WHC-SD-TP-SEP-052 ReV. 0

\subsection{PACKage CONTENTS}

\subsection{GEMERAL DESCRIPTION}

The authorized contents of the two plywood boxes consist of fixed contamination on wood, plastic, piping, rubber, and gloves. The waste inventory sheet for each box is provided in Part B, Section 3.0, which 1ists the article description and weight for the entire contents. The contents follows Part A, Section 3.0, "Package Contents," of WHC-SD-TP-SEP-020 (WHC 1994) except for a Type A quantity.

Table A-1. Nuclide Content.

\begin{tabular}{|c|c|c|c|}
\hline Nucl ide & Curies & $A_{2}$ & No. of $A_{2} s$ \\
\hline \multicolumn{4}{|c|}{ PNNL Plywood Box PNLD-95-322 } \\
\hline${ }^{90} \mathrm{Sr}$ & $1.20 \mathrm{E}-02$ & 2.7 & $4.44 E-03$ \\
\hline${ }^{137} \mathrm{Cs}$ & $9.50 \mathrm{E}-03$ & 13.5 & $7.04 \mathrm{E}-04$ \\
\hline${ }^{152} \mathrm{Eu}$ & $1.50 \mathrm{E}-04$ & 24.3 & \\
\hline${ }^{154}$ Eu & $7.00 \mathrm{E}-04$ & 13.5 & $5.19 \mathrm{E}-05$ \\
\hline${ }^{241} \mathrm{Am}$ & $3.28 \mathrm{E}-02$ & $5.41 E-03$ & $6.60 \mathrm{E}+00$ \\
\hline \multicolumn{3}{|l|}{ Total $A_{2} s$} & 6.07 \\
\hline \multicolumn{4}{|c|}{ PNNL Plywood Box PNLD-95-385 } \\
\hline${ }^{90} \mathrm{Sr}$ & $4.10 \mathrm{E}-03$ & 2.7 & $1.52 \mathrm{E}-03$ \\
\hline${ }^{137} \mathrm{Cs}$ & $3.20 \mathrm{E}-03$ & 13.5 & $2.37 \mathrm{E}-04$ \\
\hline${ }^{156}$ Eu & $8.30 \mathrm{E}-04$ & 13.5 & $6.15 \mathrm{E}-05$ \\
\hline${ }^{261} \mathrm{Am}$ & $8.50 E-03$ & $5.41 \mathrm{E}-03$ & $1.57 \mathrm{E}+00$ \\
\hline \multicolumn{3}{|l|}{ Total $A_{2} s$} & 1.57 \\
\hline
\end{tabular}

PNWL = Pacific Morthwest Motional Laboratory.

\subsection{TRANSPORT SYSTEH}

Follow the transport system and tiedown system description of WHC-SD-TP-SEP-020 (WHC 1994). Note that since this is an onsite transfer the roads between the 325 Bullding and the Wye Barricade shall be closed until the transport vehicle reaches the Wye Barricade. 
WHC-SD-TP-SEP-052 Rev. 0

\subsection{ACCEPTANCE OF PACKage FOR USAGE}

Follow the packaging acceptance criteria of WHC-SD-TP-SEP-020 (WHC 1994).

\subsection{OPERATING REQUIRENENTS}

Follow the operating requirements of WHC-SD-TP-SEP-020 (WHC 1994).

\subsection{QUALITY ASSURANCE PROgRaM}

Follow the quality assurance program of WHC-SD-TP-SEP-020 (WHC 1994).

\subsection{MAINTENANCE}

Follow the maintenance requirements of WHC-SD-TP-SEP-020 (WHC 1994).

\subsection{REFERENCES}

WHC-CM-2-14, Hazardous Material Packaging and Shipping, Westinghouse Hanford Company, Richland, Washington.

WHC, 1994, Safety Evaluation for Packaging (Onsite) Plywood Box, WHC-SD-TP-SEP-020, Rev. O-A, Westinghouse Hanford Company, Richland, Washington. 
WHC-SD-TP-SEP-052 ReV. 0

\section{PART B: PaCkage EVALUation}

\subsection{INTRODUCTION}

\subsection{SAFETY EVALUATION METHODOLOGY}

The plywood box package is evaluated in this part for normal onsite transport conditions and for compliance with the onsite transportation safety criteria found in WHC-CM-2-14. A radiological risk evaluation is included to show the package meets the accident acceptance criteria.

When possible, Safety Evaluation for Packaging (Onsite) Plywood Box (WHC 1994) is referenced to demonstrate integrity of the plywood box during normal conditions.

\subsection{EVALUATION SUMARY AND CONCLUSIONS}

As shown by the following evaluations, the plywood boxes PNLD-95-322 and PNLD-95-385 will maintain containment of their contents through all normal handling and transport conditions. Maintaining containment is demonstrated by actual testing for normal transfer conditions and meeting the requirements. Comparison of the calculated accident frequency and the estimated dose consequence associated with this shipment determines that the shipment poses no unacceptable risk. Therefore, this evaluation demonstrates that the above plywood boxes are safe for this onsite transfer of the radioactive contents listed in Part A, Section 3.0.

\subsection{CONTENTS EVALUATION}

\subsection{CHARACTERIZATION}

The contents to be transferred in the plywood boxes PNLD-95-322 and PNLD-95-385 are 6.07 $\mathrm{A}_{2}$ s and $1.57 \mathrm{~A}_{2}$ s, respectively. A solid waste storage/disposal record for each box is supplied in the appendix, Section 10.0. The nuclide contents are shown in Table B-1.

\subsection{SIZE ND MEIGHT}

The weight of the contents for box PNLD-95-322 and PNLD-95-385 is $870 \mathrm{~kg}$ $(1,914 \mathrm{lb})$ and $954.5 \mathrm{~kg}(2,104 \mathrm{lb})$, respectively. A waste inventory sheet documenting each item and its weight for each box is supplied in the following appendix. The gross weight limit for the plywood boxes is $2,268 \mathrm{~kg}$ (5,000 1b). 
WHC-SD-TP-SEP-052 Rev. 0

Table B-1. Nuclide Content.

\begin{tabular}{|c|c|c|c|}
\hline Nuclide & Curies & $A_{2}$ & No. of $A_{2} s$ \\
\hline \multicolumn{4}{|c|}{ PNNL Plywood Box PNLD-95-322 } \\
\hline${ }^{90} \mathrm{Sr}$ & $1.20 \mathrm{E}-02$ & 2.7 & $4.44 \mathrm{E}-03$ \\
\hline${ }^{137} \mathrm{Cs}$ & $9.50 \mathrm{E}-03$ & 13.5 & 7.04 E-04 \\
\hline${ }^{152} \mathrm{Eu}$ & $1.50 \mathrm{E}-04$ & 24.3 & \\
\hline${ }^{154} \mathrm{Eu}$ & $7.00 \mathrm{E}-04$ & 13.5 & $5.19 \mathrm{E}-05$ \\
\hline${ }^{24} 1_{A m}$ & $3.28 \mathrm{E}-02$ & $5.41 \mathrm{E}-03$ & $6.60 E+00$ \\
\hline \multicolumn{2}{|l|}{ Total $A_{2} s$} & & 6.07 \\
\hline \multicolumn{4}{|c|}{ PNNL Plywood Box PNLD-95-385 } \\
\hline${ }^{90} \mathrm{Sr}$ & $4.10 E-03$ & 2.7 & $1.52 E-03$ \\
\hline${ }^{137} \mathrm{Cs}$ & 3.20 E-03 & 13.5 & $2.37 \mathrm{E}-04$ \\
\hline${ }^{154} \mathrm{Eu}$ & 8.30 E-04 & 13.5 & $6.15 \mathrm{E}-05$ \\
\hline${ }^{241} \mathrm{Am}$ & $8.50 \mathrm{E}-03$ & $5.41 E-03$ & $1.57 \mathrm{E}+00$ \\
\hline \multicolumn{3}{|l|}{ Total $A_{2} S$} & 1.57 \\
\hline
\end{tabular}

PNNL = Pacific Northwest Mational Laboratory.

\subsection{RADIOLOGICAL RISK EVALUATION}

\subsection{INTRODUCTION}

Because this shipping campaign involves only two boxes in a single shipment with a combined payload of less than $10 \mathrm{~A}_{2} \mathrm{~s}$, the potential dose consequence is limited, as is the probability of a transportation accident resulting in release.

\subsection{RISK ACCEPTANCE CRITERIA}

The acceptance criteria for this shipment are based on WHC-SD-TP-RPT-001 (Mercado 1994), which limits potential dose consequences to the onsite worker to $0.05 \mathrm{~Sv}$ ( $5 \mathrm{rem}$ ) and the offsite dose consequences to $5.0 \mathrm{mSv}$ (500 mrem) if the calculated annual accident frequency is less than 1.0 E-03. The shipment is considered acceptable if the accident frequency can be shown to be less than 1.0 E-03 and the dose consequence is below the corresponding limits. Due to the minimal activity of the box contents, the potential dose consequences of the shipment are limited. 


$$
\text { WHC-SD-TP-SEP-052 Rev. } 0
$$

\subsection{ACCIDENT FREQUENCY ASSESSHENT}

The Hanford Site accident per mile rate of 2.0 E-07 from WHC-SD-TP-RPT-021 (Green et al. 1996) was used to calculate the total accident release frequency for this shipment. The distance from the 300 Area to the burial grounds in the 200 West Area is approximately $45 \mathrm{~km}$ (28 $\mathrm{mi})$; when multiplied by the accident rate, it yields a total accident release frequency of $5.6 \mathrm{E}-06$.

\subsection{DOSE CONSEQUENCE NIALSIS}

The material being shipped in the two boxes is similar in nature to the material analyzed for shipment in the Safety Analysis Report for Packaging (Onsite) Flexible Material Packaging (WHC 1996). That is, the material is contaminated equipment, rags, and debris, and no liquids or powders are allowed. Also, WHC (1996) covers shipments for any locations on the Hanford Site including the 300 Area. Accordingly, the dose consequence results in WHC (1996) can be used for the analysis of this material.

WHC (1996) develops tables of doses to the Hanford Site worker per curie of activity for a number of radionuclides. The tables are divided into beta dose, gamma dose, and inhalation dose. Using these tables and the total activity in the two boxes, the total effective dose equivalent to the onsite Hanford worker is calculated to be $0.53 \mathrm{mSv}$ ( $53 \mathrm{mrem}$ ). The spreadsheet used to develop these values is shown in Table B-2. The public receptor dose at $100 \mathrm{~m}$ is found by dividing the total inhalation dose by 30 , in keeping with the methodology used in finding the worker inhalation dose. The resulting public receptor dose is $0.017 \mathrm{mSv}(1.7 \mathrm{mrem})$. The contribution from the europium isotopes is ignored in this analysis. Given the ratios of the radionuclides present in the two boxes, the gama contribution from the europium isotopes will be small compared to the cesium dose, and the inhalation dose from the europium will be orders of magnitudes less than the americium contribution.

The dose consequence results show that the inventory contained within the two boxes fall well below the credible range upper limits. That is, the doses are much lower than the required $0.05 \mathrm{~Sv}(5 \mathrm{rem})$ to the onsite worker and $0.05 \mathrm{mSv}$ (500 mrem) to the public receptor.

\subsection{RISK EVALUATION ANO CONCLUSION}

Comparison of the calculated accident frequency and the estimated dose consequence associated with this shipment determines that the shipment poses no unacceptable risk. 
Table B-2. Total Effective Dose Equivalent Spreadsheet.

\begin{tabular}{|l|l|l|l|l|l|l|l|}
\hline & & & & & & \\
\hline & Total & Onsite & & Onsite & & Onsite & \\
\hline & Inventory & Worker & & Worker & & Worker & \\
\hline & Ci & photon dose & & beta dose & & inhalation & \\
\hline & & rad/Ci & rem & rem/Ci & rem & dose & rem \\
\hline Sr-90 & $1.61 \mathrm{E}-02$ & $3.25 \mathrm{E}-03$ & $5.23 \mathrm{E}-05$ & $8.30 \mathrm{E}+00$ & $1.34 \mathrm{E}-01$ & $5.00 \mathrm{E}-04$ & $8.05 \mathrm{E}-06$ \\
\hline Cs-137 & $1.27 \mathrm{E}-02$ & $8.80 \mathrm{E}-02$ & $1.12 \mathrm{E}-03$ & $2.20 \mathrm{E}-01$ & $2.79 \mathrm{E}-03$ & $7.90 \mathrm{E}-04$ & $1.00 \mathrm{E}-05$ \\
\hline Am-241 & $4.13 \mathrm{E}-02$ & $2.40 \mathrm{E}-02$ & $9.91 \mathrm{E}-04$ & $0.00 \mathrm{E}+00$ & $0.00 \mathrm{E}+00$ & $1.20 \mathrm{E}+00$ & $4.96 \mathrm{E}-02$ \\
\hline & & & & & & & \\
\hline Total & & & $2.16 \mathrm{E}-03$ & & $1.36 \mathrm{E}-01$ & & $4.96 \mathrm{E}-02$ \\
\hline & & & & & & & \\
\hline & & & & & & & \\
\hline & & & & & & Onsite & Offsite \\
\hline & & & & & & Worker & Receptor \\
\hline & & & & & & Total & Total \\
\hline & & & & & & EDE & EDE \\
\hline & & & & & & rem & rem \\
\hline & & & & & & & $2.68 \mathrm{E}-07$ \\
\hline & & & & & & & $3.34 \mathrm{E}-07$ \\
\hline & & & & & & & $1.65 \mathrm{E}-03$ \\
\hline & & & & & & & \\
\hline
\end{tabular}

\subsection{CONTAINMENT EVALUATION}

\subsection{CONTAINMENT SOURCE SPECIFICATION}

The source term has been established to be no more than $6.07 \mathrm{~A}_{2} \mathrm{~s}$ as shown in Part B, Section 2.0. The radioactive material, is fissile excepted (< $15 \mathrm{~g}$ ).

\subsection{NORMAL TRANSFER CONDITIONS}

The packaging will prevent any loss or dispersal of the radioactive contents visually evident and will prevent any significant increase in the radiation levels at the external surfaces when exposed to the normal transfer conditions. Normal transfer conditions are defined as Hanford environmental conditions and the penetration, drop, compression, and lifting tests as discussed in WHC-SD-TP-SEP-020 (WHC 1994). 
WHC-SD-TP-SEP-052 Rev. 0

\subsubsection{Containment Evaluation}

The plywood box was subjected to testing for environmental conditions, penetration, drop, compression, and vibration analyses to assess the ability of the box to withstand the normal transfer conditions. With restrictions invoked by WHC-SD-TP-SEP-020 (WHC 1994) based on testing information, the plywood box containment for normal transfer conditions is acceptable. A11 appropriate restrictions invoked by WHC-SD-TP-SEP-020 (WHC 1994) have been followed by boxes PNLD-95-322 and PNLD-95-385.

\subsection{ACCIDENT CONDITIOHS}

Accident conditions are evaluated Part B, Section 3.0, "Radiological Risk Evaluation." The accident release frequency is determined to be in the credible range at 5.6 E-06. The dose consequence results show that the doses are much lower than the required $0.05 \mathrm{~Sv}$ (5 rem) to the onsite worker and 0.05 mSv (500 mrem) to the public receptor. Therefore, the shipment poses no unacceptable risks due to accidents.

\subsection{SHIELDIMG EVALUATION}

The dose rates were measured for both boxes. The contact dose rate measurements are $100 \mathrm{mrem} / \mathrm{h}$ on the bottom, $12 \mathrm{mrem} / \mathrm{h}$ on the sides, and $1 \mathrm{mrem} / \mathrm{h}$ at $30 \mathrm{~cm}$ for box PNLD-95-322. For box PNLD-95-385, the maximum contact dose rate is $4 \mathrm{mrem} / \mathrm{h}$ and $1 \mathrm{mrem} / \mathrm{h}$ at $30 \mathrm{~cm}$. These dose rates are below the U.S. Department of Transportation 1 imits and are therefore acceptable.

\subsection{STRUCTURAL EVALUATION}

Follow the structural evaluation of WHC-SD-TP-SEP-020 (WHC 1994).

\subsection{THERMAL EVALUATION}

Follow the thermal evaluation of WHC-SD-TP-SEP-020 (WHC 1994).

\subsection{PRESSURE AND GAS GENERATION}

Follow the pressure and gas generation evaluation of WHC-SD-TP-SEP-02O (WHC 1994). 
WHC-SD-TP-SEP-052 Rev. 0

\subsection{PACKAGE TIEDOWN SYSTEM}

Follow the package tiedown system of WHC-SD-TP-SEP-020 (WHC 1994).

\subsection{REFERENCES}

Green, J. R., B. D. Flanagan, and H. Harris, 1996; Hanford Site Truck Accident Rate, 1990-1995, WHC-SD-TP-RPT-021, Rev. 0, Westinghouse Hanford Company, Richland, Washington.

Mercado, J. E., 1994, Report on Equivalent Safety for transportation and Packaging of Radioactive Materials, WHC-SD-TP-RPT-001, Rev. 0 , Westinghouse Hanford Company, Richland, Washington.

WHC-CM-2-14, Hazardous Material Packaging and Shipping, Westinghouse Hanford Company, Richland, Washington.

WHC, 1996, Safety Analysis Report for Packaging (Onsite) Flexible Material Packaging, WHC-SD-TP-SARP-007, Rev. 0-D, Westinghouse Hanford Company, Richland, Washington.

WHC, 1994, Safety Evaluation for Packaging (Onsite) Plywood Box, WHC-SD-TP-SEP-020, Rev. 0-A, West inghouse Hanford Company, Richl and, Washington. 


\subsection{APPENDIX: SOLID WASTE STORAGE/DISPOSAL RECORDS}

$09 / 23 / 96$ HON 10:01 FAX 509 $376 \quad 1517$

NIC FAC 325 BLDG

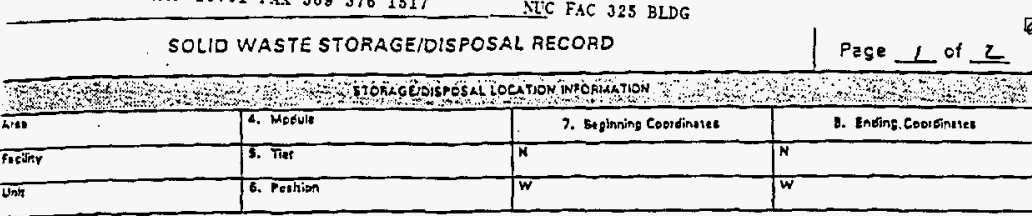

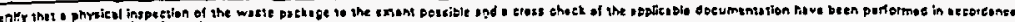
in solid kivis operaviens proceturez.

Sigmaturaceoputise

7. PRimary PN [CN]

PNLD $-95-322$

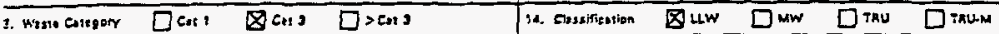

5. Is weste Ensifiest DYee 区No

E. Compary PUNL

7. Thim -1 origh

325 A BIdy. / soentea

1. Biling Cede BEO739

N/e

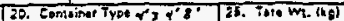

Plaues i os

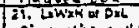

itx y w

2. eom. $y_{0}^{1 m}$

13. Di:a potioged

क. ocesim. ikg

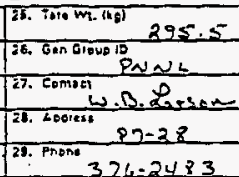

ienitymes

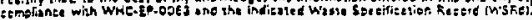

30. Signtive

$$
\text { 1). B. Paven }
$$

ग1. Dak"

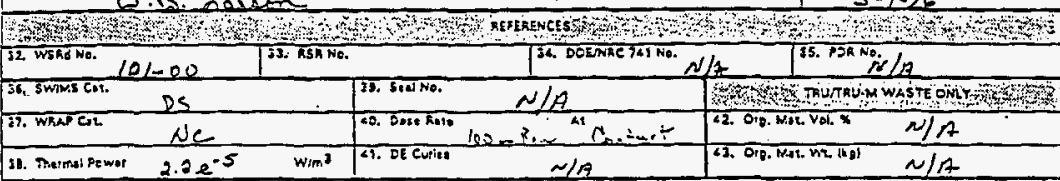

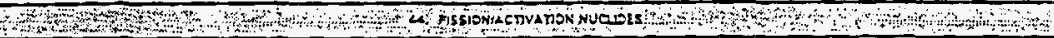

\begin{tabular}{|c|c|c|c|c|c|}
\hline Nueliao & Euties & Hutlite & Emtist & Nuelise & Curies \\
\hline $90 \mathrm{sr}$ & $1.2 z^{-2}$ & & & & \\
\hline${ }^{37} \mathrm{Cs}$ & $9.5 \mathrm{e}^{-3}$ & & & & \\
\hline $1 \leqslant 2$ Eu & $1.5 e^{-4}$ & & & & \\
\hline${ }^{15 \%} \mathrm{EL}$ & $202^{-4}$ & & & & \\
\hline & & & & 45. TOTAL Cwins & Nha \\
\hline
\end{tabular}

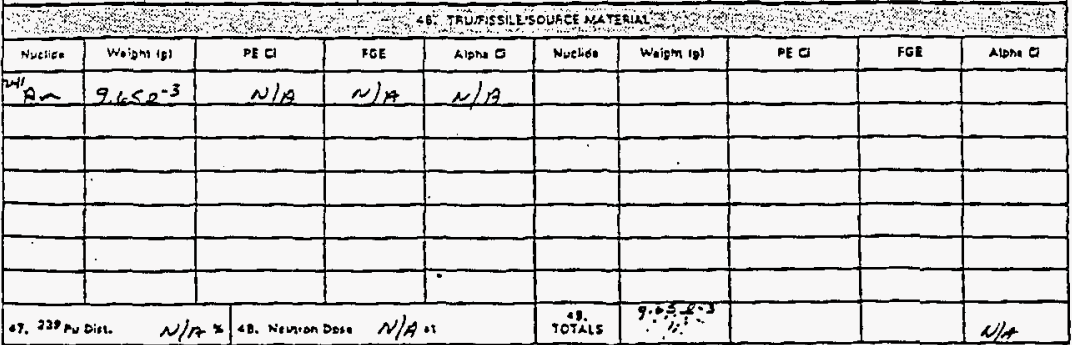

a.cosicto 105si 


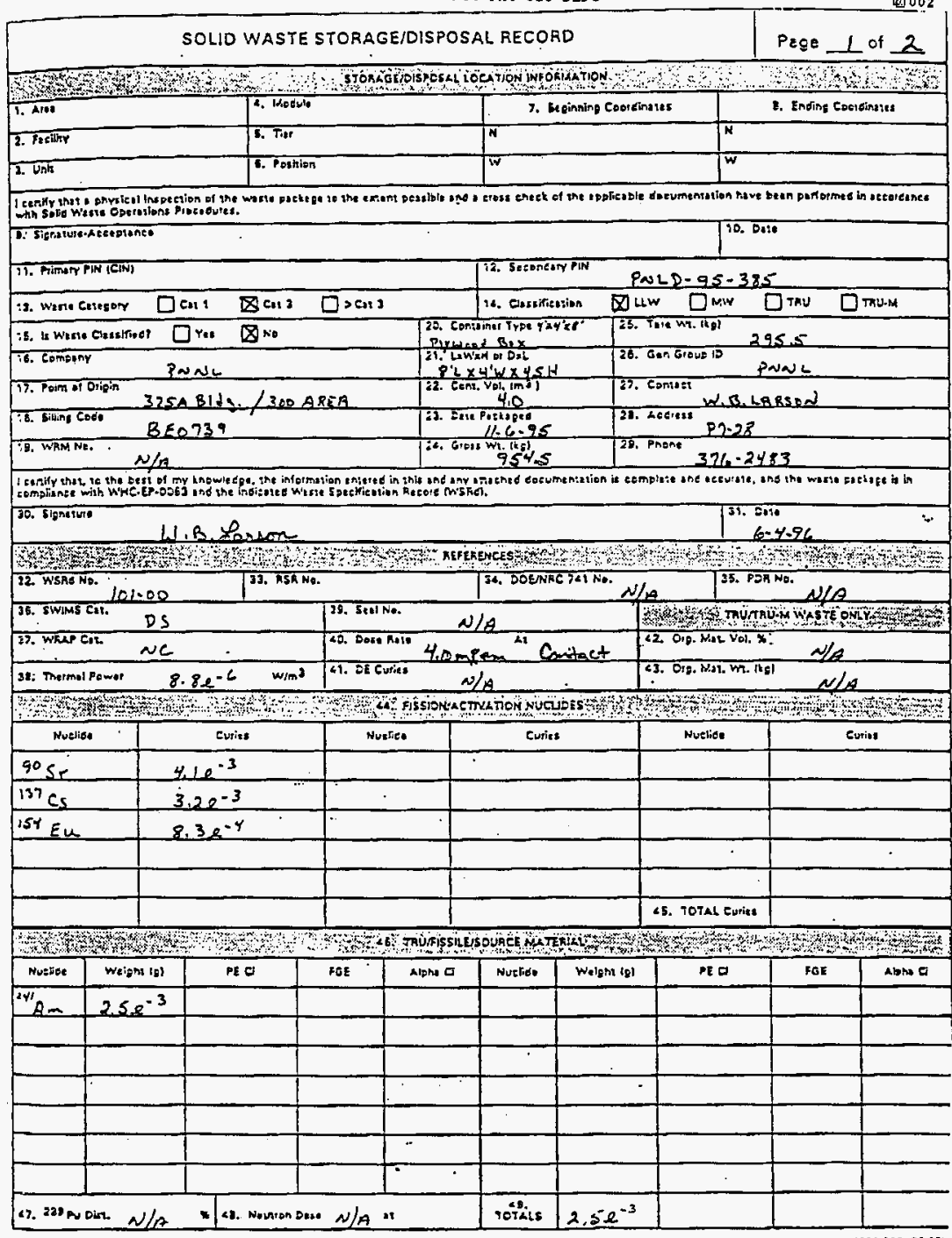




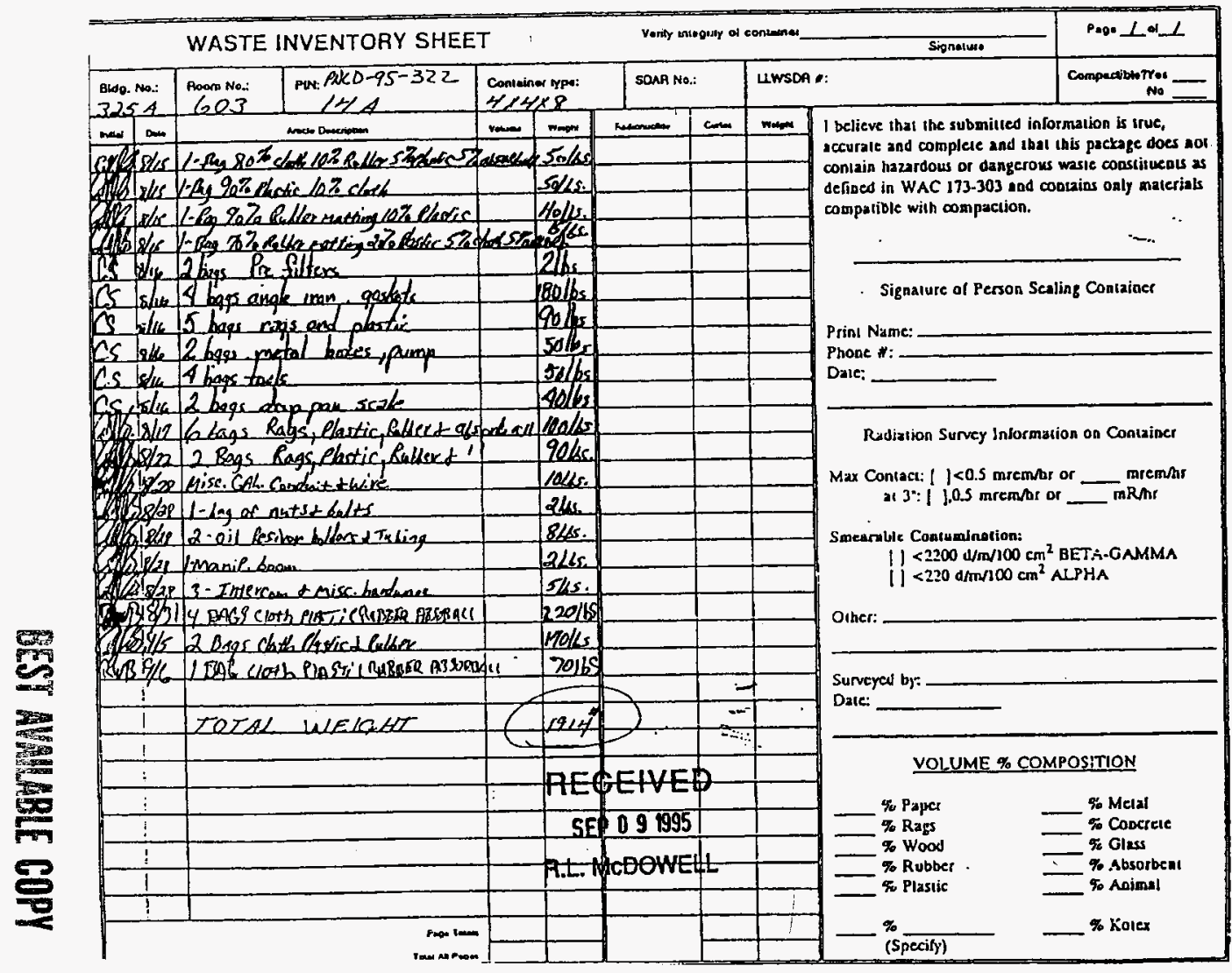




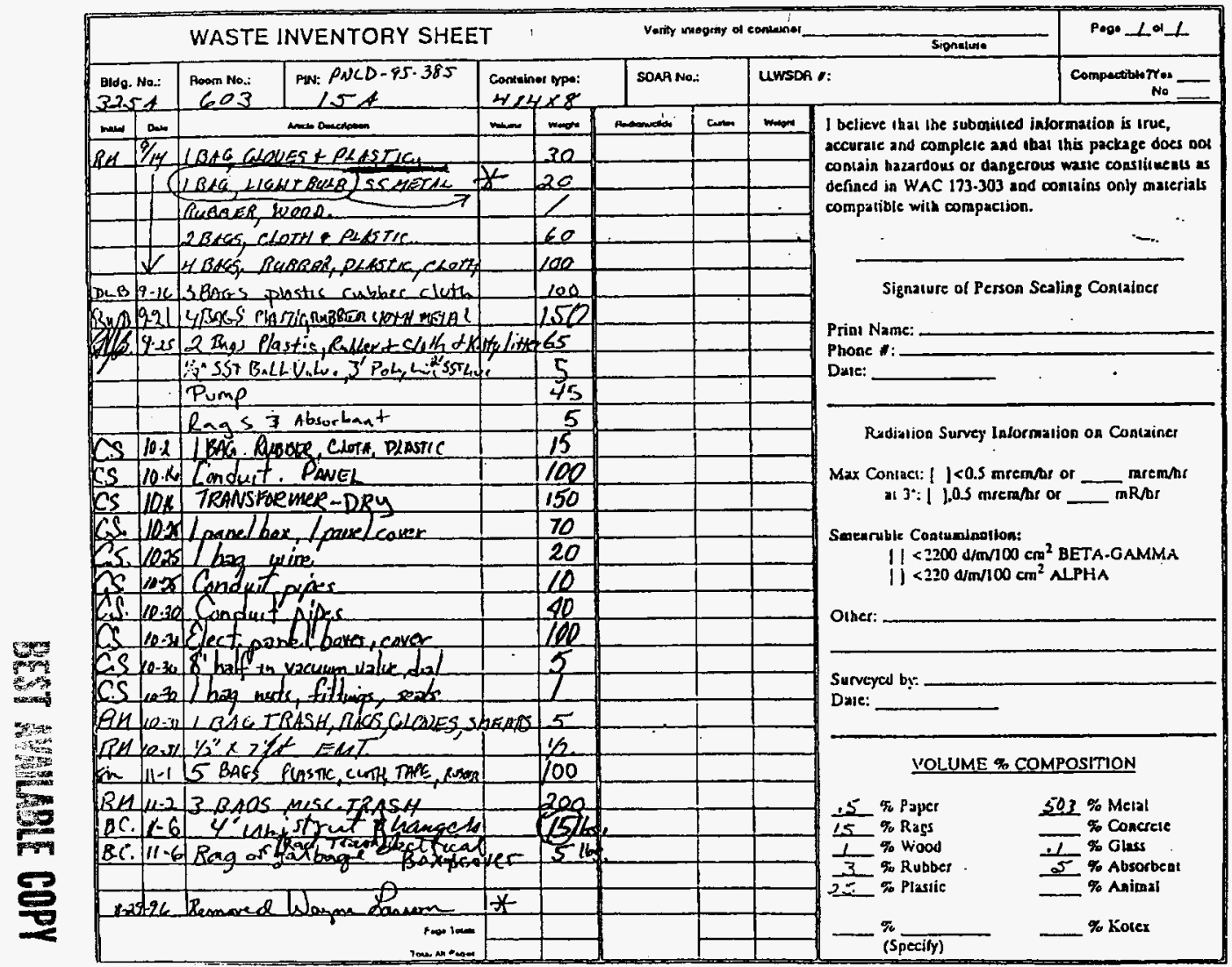




\begin{tabular}{|c|c|c|c|c|c|c|}
\hline \multicolumn{7}{|c|}{ DISTRIBUTION SHEET } \\
\hline \multirow{2}{*}{$\begin{array}{l}\text { To } \\
\text { Distribution }\end{array}$} & \multirow{2}{*}{\multicolumn{4}{|c|}{$\begin{array}{l}\text { From } \\
\text { Packaging Engineering }\end{array}$}} & \multicolumn{2}{|c|}{ Page 1 of 1} \\
\hline & & & & & \multicolumn{2}{|c|}{ Date Sept. 25, 1996} \\
\hline \multicolumn{5}{|l|}{ Project Title/Work Order } & \multicolumn{2}{|c|}{ EDT No. 618182} \\
\hline \multicolumn{5}{|c|}{$\begin{array}{l}\text { Safety Evaluation for Packaging for Two Plywood Boxes } \\
\text { (WHC-SD-TP-SEP-052) }\end{array}$} & \multicolumn{2}{|c|}{ ECN No. $\quad N / A$} \\
\hline Name & & MSIN & $\begin{array}{c}\text { Text } \\
\text { With All } \\
\text { Attach. }\end{array}$ & Text Only & $\begin{array}{l}\text { Attach./ } \\
\text { Appendix } \\
\text { Only }\end{array}$ & $\begin{array}{l}\text { EDT/ECN } \\
\text { Only }\end{array}$ \\
\hline $\begin{array}{l}\text { R. L. Clawson } \\
\text { B. D. Flanagan } \\
\text { J. G. Field } \\
\text { C. R. Hoover } \\
\text { W. B. Larson } \\
\text { D. W. McNally } \\
\text { M. J. Riess } \\
\text { Central Files }\end{array}$ & & $\begin{array}{l}\text { G1-13 } \\
\text { Gl-11 } \\
\text { Gl-11 } \\
\text { Gl-11 } \\
\text { P7-28 } \\
\text { G1-11 } \\
\text { P7-75 } \\
\text { A3-88 }\end{array}$ & $\begin{array}{l}x \\
x \\
x \\
x \\
x \\
x \\
x \\
x\end{array}$ & & & \\
\hline WHC-SD-TP-SEP-052 File & & Gl-11 & $x$ & & & \\
\hline
\end{tabular}

